\title{
Environmental Factors to Promote the Use of a Public Park in Adults
}

\author{
Fatores ambientais que estimulam o uso de um parque público em adultos
}

\author{
AUTHOR'S \\ Alfredo Leopoldo Enrique Messenger \\ Valenzuela ${ }^{1}$ (D) \\ Ana Carolina Belther Santos ${ }^{1}$ (D) \\ Marcelo Dutra Della Justina ${ }^{1}$ (D) \\ Thuany Stahelin Kuhn² (ID \\ Joris Pazin ${ }^{2}$ (iD) \\ Cassiano Ricardo Rech ${ }^{1}$ (D) \\ 1 Federal University of Santa Catarina. Department \\ of Physical Education, Florianópolis, Santa \\ Catarina, Brazil. \\ 2 Santa Catarina State University. Department of \\ Physical Education, Florianópolis, Santa Catarina, \\ Brazil.
}

\section{CORRESPONDING}

Alfredo Leopoldo Enrique Messenger

Valenzuela

alfredomessenger@gmail.com

Rodovia Amaro Antônio Vieira, 189 -

apto.106, Itacorubi, Florianópolis, Santa

Catarina, Brazil. CEP: 88034-101.

DOI

$10.12820 /$ rbafs. $23 \mathrm{e} 0049$

\section{(cc) BY-NC-SA}

Este obra está licenciado com uma Licença Creative Commons Atribuição-NãoComercialCompartilhalgual 4.0 Internacional.

\begin{abstract}
The aim of this study was to describe environmental factors that motivate public park use according to users' sociodemographic characteristics. A cross-sectional study was carried out in 2014/2015 in a park in the city of Florianopolis, Brazil. A face-to-face interview was performed, including sociodemographic data and environmental factors that stimulate park use. Descriptive analysis, chi-square and $\mathrm{Z}$-tests were used to compare the proportions between groups, adopting a significance level of $\mathrm{p}<0,05$. The sample included 377 park users, aged 18 years or older $(59.7 \%$ women). The architectural beauty of structures, geographic location, technological factors, normative policies, values and attitudes were reported as the main factors that motivate park use $(\mathrm{p}<0.05)$. The presence of equipment and public programs in parks were more frequently mentioned as motivational factors for park use among women than men $(p>0.05)$. Architectural structures and notice boards and posters had higher proportions among users who had an elementary and high school level $(\mathrm{p}<0.05)$. In conclusion, the existing environmental factors seem to have an impact on the motivation for park use, changing according to users' sociodemographic aspects.
\end{abstract}

Keywords: Environment; Urban parks; Demographic data; Leisure activities.

RESUMO

O objetivo deste estudo foi descrever os fatores ambientais que estimulam o uso de um parque público de acordo com as características sociodemográficas dos frequentadores. Foi realizado um estudo transversal em um parque público de Florianópolis, em 2014/2015. Foi aplicada uma entrevista face-a-face sobre características sociodemográficas e sobre fatores ambientais que podem estimular o uso do parque. Utilizou-se a análise descritiva e os testes Qui-quadrado e teste $Z$ para comparar as proporçôes entre grupos, adotando-se um nivel de significancia de $p<0,05$. Participaram do estudo 377 frequentadores do parque (59,7\% mulheres), com 18 ou mais anos de idade. A beleza, localização geográfica, fatores tecnológicos, arquitetônicos, politicas normativas, valores e atitudes foram os fatores ambientais mais relatados como os que estimulam o uso do parque $(p<0,05)$. A presença de equipamentos e programas públicos no parque foram os fatores mais relatados entre mulheres, quando comparado aos homens $(p>0,05)$. A beleza arquitetônica das estruturas e a presença de cartazes/quadros informativos foram os fatores com motivadores mais relatados entre aqueles com ensino fundamental e médio $(p<0,05)$. Os fatores ambientais existentes parecem ter impacto na motivação para 0 uso do parque e variam de acordo com as variáveis sociodemográficas dos frequentadores.

Palavras-chave: Ambiente; Parques urbanos; Dados demográficos; Atividade de lazer.

\section{Introduction}

Physical inactivity currently accounts for nearly $10 \%$ of the main non-communicable chronic diseases worldwide $^{1}$. This is partly due to the increase in individuals' involvement in activities requiring less energy expenditure, such as watching TV and sitting in the workplace for long periods of time ${ }^{2,3}$ or during transport ${ }^{4}$. One of the strategies used to reduce physical inactivity has been the creation and maintenance of public open spaces such as squares and public parks ${ }^{5,6}$.
This recommendation is based on the positive relationship between greater access to public spaces and better health indicators ${ }^{7,8}$. Individuals who live near parks are more physically active and visit these locations more frequently ${ }^{9}$. Thus, promoting the use of such locations can contribute to the increase in physical activity levels ${ }^{10}$. On the other hand, studies performed in developed countries have pointed out that greater use of public open spaces is associated with the characteristics of locations, such as distance from home and amount, 
diversity and quality of pieces of equipment ${ }^{11-13}$.

In this sense, identifying the barriers and facilitators for the use of public open spaces can be an important tool to promote their use. Barriers can be categorized as behavior-inhibiting factors, while attractive factors are facilitators for the use of public open spaces. A study performed in a public park in the city of Curitiba, Southern Brazil, showed that climatic conditions such as rain and cold are relevant barriers to park use, especially for individuals who are older and have a lower income ${ }^{14}$. Additionally, excess body weight can be an important barrier to one's involvement in physical activities in public parks. This is an important fact, as the prevalence of overweight in adults is higher than $50 \%{ }^{15}$. Moreover, individuals who visit open spaces tend to have lower body mass index values ${ }^{16}$. On the other hand, the aesthetical factor, geographic location, presence of technological and architectural items, normative policies, values and attitudes, accessibility and closeness to home can be important environmental facilitators for park use ${ }^{17-19}$.

Thus, identifying the conditions associated with the environment of public open spaces that motivate individuals to visit these locations will enable managers, urban planners and Physical Education professionals to offer more possibilities of use of such spaces as environments for physical activity promotion. Additionally, it is necessary to broaden the debate on the differences in public park users' perception of socio-demographic characteristics such as sex, age group and level of education. This is because, among other things, access to public open spaces is still low and restricted to medium- and high-income locations ${ }^{20}$, especially in Brazil. Therefore, the present study aimed to describe environmental factors that promote public park use in the city of Florianópolis, Southern Brazil, according to users' socio demographic characteristics.

\section{Methods}

An descriptive cross-sectional study was performed in a public park in the city of Florianópolis, capital of Santa Catarina state, in Southern Brazil. This city has an estimated population of 485,838 individuals and a Human Development Index (HDI) of $0.847^{21}$. All procedures performed in this study were approved by the Research Ethics Committee of the Santa Catarina State University (number 105228/2014).

Aiming to perform this study, Parque de Coqueiros was the location purposefully selected, as this is the only public park on the city's continental area with physical infrastructure and equipment for exercises and leisure programs. This park is located in the Coqueiros district and it was built by the Society of Friends of Coqueiros District between 1999 and 2000. Currently, this park is managed by the Florianópolis City $\mathrm{Hall}^{22}$ and the population has an average income of $\mathrm{R} \$ 5,376.00$ (US $\$ 1,448.00)^{22}$. An analysis performed through systematic observation revealed that this location includes 11 pieces of equipment for physical activity practice with good quality ${ }^{20}$.

The study population was comprised of all park users who were found in this location on the collection days. The sample selection process was intentional and by convenience. In all, 457 users aged more than 18 years were approached and the research objectives clarified to them. Of these, 395 (86.43\%) accepted to participate. The analysis of statistical power of the sample size was performed "post hoc", showing that the final sample (377 individuals after losses) showed a power of 0.90 for the chi-square test, an alpha value of 0.05 and an effect size of 0.12 (Software $G^{*}$ Power 3.1.9.3).

Questionnaires were applied between August and October 2014 and between March and April 2015, totaling 50 visits to the park with collections on two weekdays and one weekend day, from 9:00am to $12: 00 \mathrm{pm}$ and from $2: 00 \mathrm{pm}$ to $5: 00 \mathrm{pm}$.

Environmental factors that promote park use were assessed through a scale of self-perception of the environment for physical activity practice, which has been validated for studies in Brazil $^{23}$ and applied to similar research in this country ${ }^{14,24}$. This scale is comprised of four factors, distributed into 16 indicators. Geographical factors were grouped according to the following indicators: rainfall in the park, air pollution in the park, geographic beauty of the park, geographic location of the park and walking/running tracks in the park. Technological/architectural factors were as follows: available equipment, parking area in the park and the architectural beauty of structures.

Moreover, the following political-normative factors were included: public physical activity programs in the park, notice boards/posters about physical activity in the park, emergency services in the park, and public safety services and traffic regulations in the nearby area. Finally, factors, values and attitudes are comprised of the following indicators: users' behavior observed in the park, support and encouragement from friends, and value attributed to the park by the community. 
The instrument questions were assessed with the Likert scale of five points as follows: 1) greatly inhibits; 2) inhibits; 3) neither inhibits nor encourages; 4) encourages; and 5) greatly encourages. For the operationalization in the descriptive analyses and analyses of association with socio-demographic characteristics, these categories were dichotomized: encourages (encourages + greatly encourages) and does not encourage (greatly inhibits, inhibits, and neither inhibits nor encourages).

In addition, users reported sex (male and female), age (years), level of education (school years), body weight $(\mathrm{kg})$ and height $(\mathrm{cm})$. Age was categorized into two levels (adults $\leq 39$ years; $\geq 40$ years), school years were grouped into two categories (primary and/or secondary education; higher education). Body mass index (BMI) was calculated with the weight and height variables and individuals were thus classified: underweight $\left(\right.$ BMI $\left.<18.4 \mathrm{~kg} / \mathrm{m}^{2}\right)$, normal $\left(\mathrm{BMI}<25 \mathrm{~kg} / \mathrm{m}^{2}\right)$, overweight (IMC $\geq 25 \mathrm{~kg} / \mathrm{m}^{2}$ ) or obese (IMC $\geq 30 \mathrm{~kg}$ / $\left.\mathrm{m}^{2}\right)^{25}$. For the BMI to be shown, the classification was dichotomized into normal BMI (underweight + normal) and overweight (overweight + obesity). Additionally, time of transport from home to park in minutes was also reported and subsequently categorized $(<10$ minutes; $\geq 10$ minutes). Finally, participants answered whether they practiced regular physical activities in the park or not (yes; no).

Absolute and relative frequencies were used to describe the sample in the data analysis. Chi-square test was employed to compare the proportions according to socio-demographic variables (sex, age group and level of education). The comparison of proportions between groups of socio-demographic variables in the total sample was performed with the Z-test of proportions. SPSS $^{\oplus}$, version 25.0, and MedCalc ${ }^{\circledR}$, version 18.2.1, were used in the analyses, adopting a significance level of $5 \%$.

\section{Results}

Among all 395 participants in the present study, 18 questionnaires were not complete and, as a result, were excluded from the analysis. Of all 377 users included (59.7\% women; mean age of $37.01 \pm 12.44$ years), the majority were aged between 18 and 39 years (66.3\%), had complete higher education (56.9\%) and a positive health perception (83.8\%), lived more than 10 minutes away from park (60.6\%) and performed physical activity in the park (61.7\%). Regarding sex, there was a predominance of young women ( $<40$ years) with a normal BMI $(\mathrm{p}<0.05)$. The other characteristics did not differ between sexes (Table 1 ).

Table 1 - Sample characteristics of users of a public park in Florianópolis, Brazil, 2014/2015 (n = 377).

\begin{tabular}{|c|c|c|c|c|c|c|c|}
\hline \multirow{2}{*}{ Variable } & \multicolumn{2}{|c|}{ Total } & \multicolumn{2}{|c|}{ Male } & \multicolumn{2}{|c|}{ Female } & \multirow{2}{*}{$\mathrm{p}$} \\
\hline & $\mathrm{n}$ & $\%$ & $\mathrm{n}$ & $\%$ & $\mathrm{n}$ & $\%$ & \\
\hline Total sample & 377 & 100.0 & 152 & 40.3 & 225 & 59.7 & \\
\hline Age range & & & & & & & 0.035 \\
\hline $18-39$ years & 242 & 66.3 & 85 & 59.4 & 157 & 70.7 & \\
\hline$\geq 40$ years & 123 & 33.7 & 58 & 40.6 & 65 & 29.3 & \\
\hline Level of education & & & & & & & 0.238 \\
\hline Primary and/or secondary education & 162 & 43.1 & 59 & 39.1 & 103 & 45.8 & \\
\hline Higher education & 214 & 56.9 & 92 & 60.9 & 122 & 54.2 & \\
\hline BMI classification & & & & & & & 0.001 \\
\hline Normal $^{2}$ & 180 & 49.5 & 50 & 34,0 & 130 & 59.9 & \\
\hline Overweight & 184 & 50.5 & 97 & 66.0 & 87 & 40.1 & \\
\hline Health perception & & & & & & & 0.210 \\
\hline Excellent/good & 316 & 83.8 & 136 & 89.5 & 180 & 80.0 & \\
\hline Fair/poor & 61 & 16.2 & 16 & 10.5 & 45 & 20.0 & \\
\hline Travel time to the park & & & & & & & 0.897 \\
\hline$<10$ minutes & 143 & 39.4 & 59 & 40.1 & 84 & 38.9 & \\
\hline$\geq 10$ minutes & 220 & 60.6 & 88 & 59.9 & 132 & 61.1 & \\
\hline Performed PA in the park & & & & & & & 0.071 \\
\hline Yes & 232 & 61.7 & 102 & 67.5 & 130 & 57.8 & \\
\hline No & 144 & 38.3 & 49 & 32.5 & 95 & 42.2 & \\
\hline
\end{tabular}

$\mathrm{PA}$ = physical activity; BMI = Body mass index; a = Two participants were underweight $\left(<18.4 \mathrm{~kg} / \mathrm{m}^{2}\right)$ and were thus placed in the "normal" category. 
Among the environmental factors reported as motivators for park use, the following stood out: geographical aspects (geographic location and beauty), architectural-technological aspects (presence of walking/ running tracks, equipment and architectural beauty of structures), values and attitudes (user behavior, support and encouragement from friends, and value attributed to the park). The least reported factors as promoters of park use were rainfall, perception of lack of safety, and lack of emergency services in the park $(p<0.05)$ - Table 2 .

In the stratified analysis, according to the socio-demographic variables (Figure 1), the presence of available equipment and public programs in the park was a factor that encouraged park use, with a higher frequency among women when compared to men ( $<<0.05)$. Additionally, users with a primary/secondary education level reported factors such as the architectural beauty of structures and notice boards/posters more frequently, when compared to those with higher education ( $\mathrm{p}$ $<0.05$ ). Rainfall was less frequently reported as an encouraging factor for park use among those with higher education, when compared to others with a lower level of education $(97.7 \%$ versus $92.0 \%$; $p<0.05)$.

\section{Discussion}

The results of the present study indicate that geographic, technological and architectural, and political-normative factors, values and attitudes are important to promote public park use. Moreover, the presence of equipment and public programs for physical activity in the park were important motivational factors among women, whereas the architectural beauty of the park was associated with greater encouragement for use among those with a lower level of education. These results emphasize the importance of maintaining attraction factors to increase public park use. Moreover, the presence of certain environmental factors that promote park use was found to be important for population subgroups such as women and individuals with a lower level of education.

The majority of users were women. This result is in agreement with another study ${ }^{25}$ performed in the same public park, aimed at identifying the mediators for physical activity practice during leisure time among park users, with women being more representative. In contrast, certain studies ${ }^{14,24}$ showed that men predominated. The fact that women were more prevalent in Coqueiros

Table 2 - Percentage of perceived indicators that do not stimulate and indicators that stimulate public park use in adults, 2014/2015 ( $\mathrm{n}=377)$.

\begin{tabular}{|c|c|c|c|c|c|}
\hline \multirow{2}{*}{ Factor / Indicator } & \multicolumn{2}{|c|}{ Does not stimulate } & \multicolumn{2}{|c|}{ Stimulates } & \multirow{2}{*}{$\mathrm{p}$} \\
\hline & $\mathrm{n}$ & $\%$ & $\mathrm{n}$ & $\%$ & \\
\hline \multicolumn{6}{|l|}{ Geographic } \\
\hline Incidence of rainfall in the park & 359 & 95.2 & 18 & 4.8 & $<0.001$ \\
\hline Air pollution in the park & 226 & 59.9 & 151 & 40.2 & $<0.001$ \\
\hline Geographic beauty of the park & 35 & 9.3 & 342 & 90.7 & $<0.001$ \\
\hline Geographic location of the park & 34 & 9.0 & 343 & 91.0 & $<0.001$ \\
\hline \multicolumn{6}{|l|}{ Architectural-technological } \\
\hline Presence of walking/running tracks & 84 & 22.3 & 293 & 77.7 & $<0.001$ \\
\hline Available equipment (seats, bars) & 151 & 40.3 & 225 & 59.8 & $<0.001$ \\
\hline Parking area in the park & 184 & 49.1 & 191 & 50.9 & 0.717 \\
\hline Architectural beauty of the park & 144 & 38.2 & 233 & 61.8 & $<0.001$ \\
\hline \multicolumn{6}{|l|}{ Political-normative } \\
\hline Public program for PA in the park & 193 & 51.3 & 183 & 48.7 & 0.608 \\
\hline Posters/ notice boards about PA in the park & 249 & 66.2 & 127 & 33.8 & $<0.001$ \\
\hline Emergency care service in the park & 279 & 74.2 & 97 & 25.8 & $<0.001$ \\
\hline Public safety services near the park & 279 & 74.0 & 98 & 26.0 & $<0.001$ \\
\hline Traffic rules in the vicinity & 222 & 58.9 & 155 & 41.1 & $<0.001$ \\
\hline \multicolumn{6}{|l|}{ Values and attitudes } \\
\hline Observed behavior of users in the park & 135 & 35.9 & 241 & 64.1 & $<0.001$ \\
\hline Support and encouragement from friends & 120 & 31.9 & 256 & 68.1 & $<0.001$ \\
\hline Value assigned to the park by the community & 78 & 21.0 & 294 & 79.0 & $<0.001$ \\
\hline
\end{tabular}

$\mathrm{PA}=$ physical activity; $\mathrm{a}=\mathrm{In}$ this category, the factors that inhibit, do not inhibit and do not stimulate were grouped. 
a)

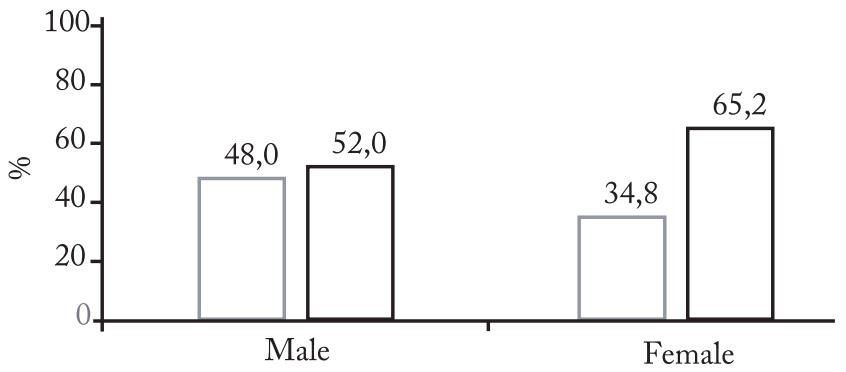

c)

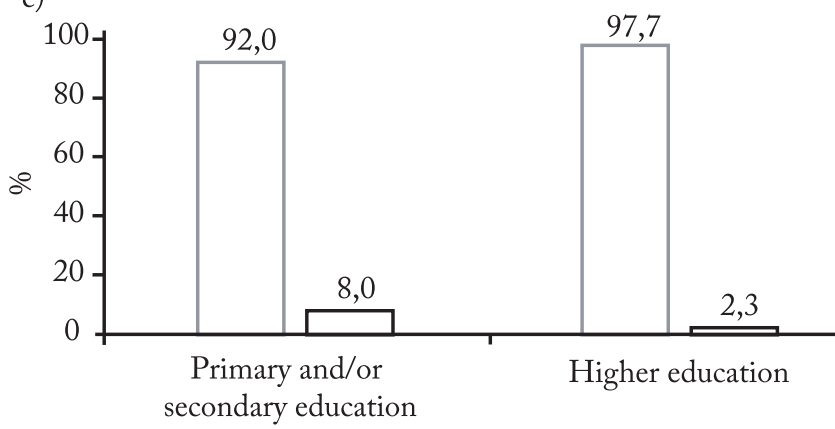

b)

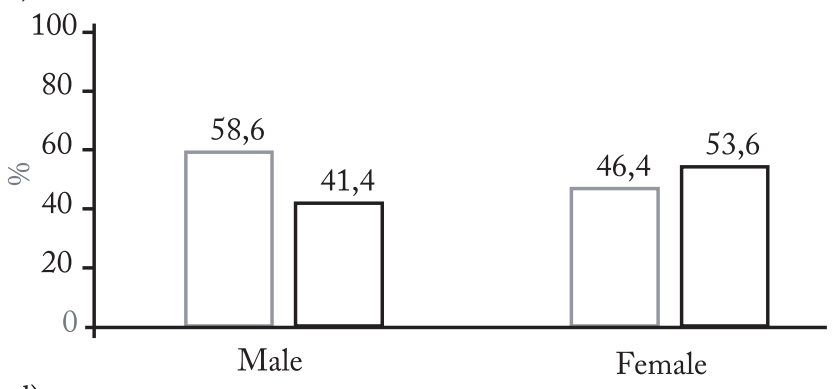

d)

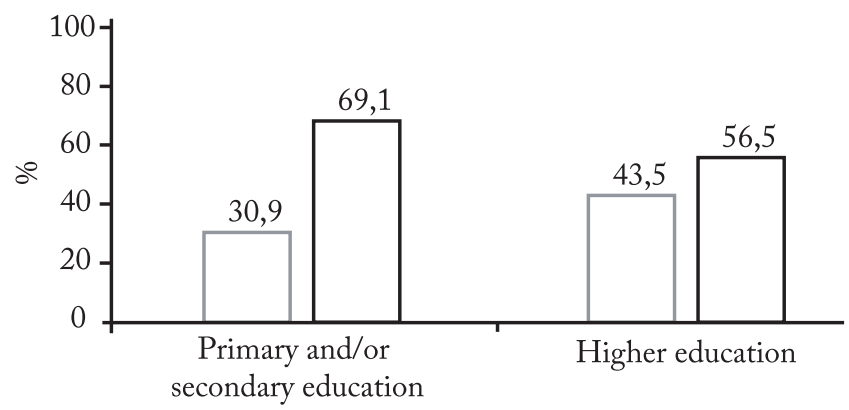

e)

Does not stimulate - Stimulates

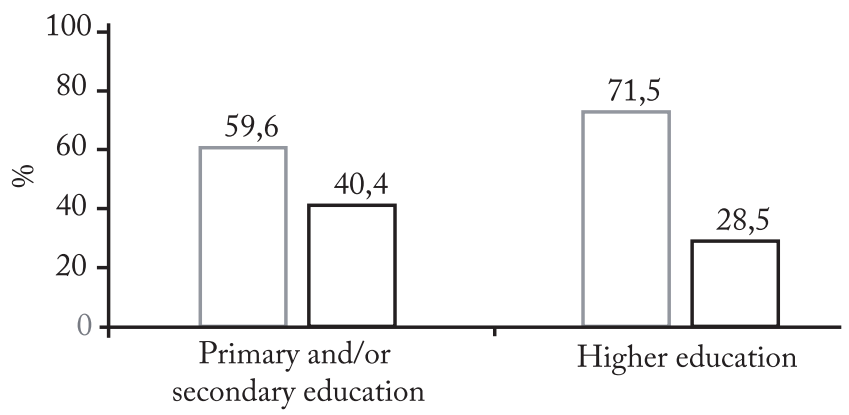

Figure 1 - Environmental factors associated with the motivation for public park use in Florianopolis, according to sociodemographic variables. Florianopolis, Brazil, 2014/2015 ( $\mathrm{n}=377)$.

Legend: a) Association between "equipment available in the park" and sex (male and female); p < 0.05. b) Association between "public programs for physical activity in the park" and sex (male and female); $<<0.05$. c) Association between "rainfall in the park" and level of education (primary or secondary education and higher education); $p<0.05$. d) Association between "architectural beauty of structures" and education (primary or secondary education and higher education); $\mathrm{p}<0.05$. e) Association between "posters / notice boards about physical activity in the park" and education (primary or secondary education and higher education); $p<0.05$.

park could be a particular characteristic of this location, where they feel more encouraged to use it. Regarding level of education, the data showed that, regardless of sex, the majority of users had a higher education level, a fact that is in agreement with the literature ${ }^{24}$.

Geographic location and beauty of park were considered as motivational factors for park use. This result is similar to what has been found in the literature ${ }^{19}$. Greater access to parks tends to stimulate the use of such spaces, enabling them to become good strategies for physical activity promotion. Additionally, the aesthetics and beauty of the locations have also been a variable associated with greater park use and higher physical activity level ${ }^{14}$. These results emphasize the need to increase access to and maintenance of public parks, as location and beauty are relevant aspects that encourage individuals to use such spaces.

Another important result points out that the presence of architectural structures in the park, such as walking/running tracks and equipment, represent factors that encourage park use in the study sample. Through a telephone survey, another study identified that, the higher the number of pieces of equipment available for physical activity, the greater the chance of 
such locations being used ${ }^{26}$. Thus, the more pieces of equipment for physical activity available, the more people will feel encouraged to go to a park, a factor that can be decisive for public health, due to the higher number of individuals changing their daily life habits positively.

The value attributed to the location and support and encouragement of friends were also important factors to promote park use. Moreover, the lack of a companion was considered to be one of the main perceived barriers to physical activity practice in other studies ${ }^{24}$. Considering the area of physical activity promotion, interventions aimed at enabling social interactions tend to be more successful, which indicates the importance of social support for physical activity practice and, consequently, for park use.

The presence of traffic rules in the vicinity of the park was also reported as a factor promoting public park use. similar results were found in the literature ${ }^{14}$. In contrast, when perceiving lack of safety and emergency services, users do not feel encouraged to use a park. These same indicators have also been observed in other studies ${ }^{27,28}$. Climatic conditions, especially rainfall, were also considered to be an aspect that discourages park use. This result corroborates those found in the literature ${ }^{28,29}$. Park use was associated with adequate climatic conditions, which shows the need to pay attention to this issue. Florianópolis has well-defined seasons and rainfall is heavy during certain times of the year. In this sense, park users are affected by climatic conditions. Thus, enabling sheltered environments in public parks for physical activity practice on rainy days is one way to remedy this inhibiting factor.

The present study showed some limitations. One of them is the intentional selection method with an unintentional selection. This fact could have led to selection bias, as individuals who accepted to participate in this study were those more motivated to use the park. Additionally, stratified analyses by age and level of education created a sample with a low number of participants, thus resulting in broad categories. Therefore, future studies should include larger samples, aiming to stratify more categories with such influence. Finally, the data from the present study are limited to Coqueiros park users. Consequently, the results cannot be generalized to other studies.

In conclusion, the environmental factors that encourage public park use more frequently reported by users were as follows: presence and maintenance of adequate structures for physical activity, emergency services, safety, notice boards and posters, architectural beauty of structures, and public programs in the park aimed at encouraging its use. Additionally, some motivational factors stood out among female users and those with a higher education level. These results emphasize the need for professionals, public managers and urban planners to analyze such aspects when the objective is to promote park use. In this sense, open public spaces showing such characteristics can be interesting ways to encourage physical activity practice in the population.

\section{Conflicts of interest}

The authors declare no conflicts of interest.

\section{Acknowledgements}

The authors would like to thank the Research and Study Group on Urban Environment \& Health and the students who performed the data collection.

\section{Author contributions}

Valenzuela ALEM, Santos ACB and Justina MDD participated in the article conception, data analysis and interpretation, and final text review. Kuhn TS participated in the data collection, data tabulation and final text review. Pazin J participated in the article conception, data collection and final text review. Rech CR participated in the data analysis and interpretation, and final text review.

\section{References}

1. Lee I, Shiroma EJ, Lobelo F, Puska P, Blair SN, Katzmarzyk PT. Effect of physical inactivity on major non-communicable diseases worldwide: an analysis of burden of disease and life expectancy. Lancet. 2012;380(9838):219-29.

2. Jans MP, Proper KI, Hildebrandt VH. Sedentary behavior in dutch workers. Differences between occupations and business sectors. Am J Prev Med. 2007;33(6):450-4.

3. Turi BC, Codogno JS, Fernandes RA, Lynch KR, Kokubun E, Monteiro HL. Time trends in physical activity of adult users of the Brazilian national health system: 2010-2014. Longitudinal study. Sao Paulo Med J. 2017;135(4):369-75.

4. Yang L, Hu L, Hipp JA, Imm KR, Schutte R, Stubbs B, et al. Cross-sectional associations of active transport, employment status and objectively measured physical activity: analyses from the national health and nutrition examination Survey. J Epidemiol Community Health. 2018;72(9):764-9.

5. Sallis JF, Cervero RB, Ascher W, Henderson KA, Kraft MK, Kerr J. An ecological approach to creating active living communities. Ann Rev Public Health. 2006;27(1):297-22.

6. Camargo DM, Ramírez PC, Quiroga V, Ríos P, Fermino RC, Sarmiento OL. Physical activity in public parks of high and low socioeconomic status in Colombia using observational methods. J Phys Act Health. 2018;15(8):581-91.

7. Sugiyama T, Leslie E, Giles-Corti B, Owen N. Associations of neighbourhood greenness with physical and mental health: do walking, social coherence and local social interaction explain the relationships? J Epidemiol Community Health. 2008;62(5):9. 
8. SullivanWC,Chang C.Mental health and the built environment. in: Dannenberg AL, Frunkin H, Jackson RJ. Making healthy places. Washington: Island Press; 2011.p. 106-16.

9. McCormack GR, Rock M, Toohey AM, Hignell D. Characteristics of urban parks associated with park use and physical activity: a review of qualitative research. Health Place. 2010;16(4):712-26.

10. Fermino RC, Hallal PC, Reis RS. Frecuencia de uso de los parques y práctica de actividad física en adultos de Curitiba, Brazil. Rev Bras Med Esporte. 2017;23(4):264-70.

11. Humpel N, Owen N, Leslie E. Environmental factors associated with adults' participation in physical activity: A review. Am J Prev Med. 2002;22(3):188-99.

12. Lee RE, Mama SK, Adamus-Leach HJ, Soltero EG. Contribution of neighborhood income and access to quality physical activity resources to physical activity in ethnic minority women over time. Am J Health Promot. 2015;29(4):210-6.

13. Van Cauwenberg J, Cerin E, Timperio A, Salmon J, Deforche B, Veitch J. Park proximity, quality and recreational physical activity among mid-older aged adults: moderating effects of individual factors and area of residence. Int J Behav Nutr Phys Act. 2015;12:46.

14. Silva DAS, Petroski EL, Reis RS. Barreiras e facilitadores de atividades físicas em frequentadores de parques públicos. Motriz. 2009;15(2):219-27.

15. Ministério da Saúde. Protocolos do Sistema de Vigilância Alimentar e Nutricional. Brasília: Ministério da Saúde; 2016.

16. Papas MA, Alberg AJ, Ewing R, Helzlsouer KJ, Gary TL, \& Klassen, A. C. The built environment and obesity. Epidemiol Rev. 2007;29(1);129-43.

17. Kärmeniemi M, Lankila T, Ikäheimo T, Koivumaa-Honkanen $\mathrm{H}$, Korpelainen R. The built environment as a determinant of physical activity: a systematic review of longitudinal studies and natural experiments. Ann Behav Med. 2018;52(3):239-51.

18. Hunter RF, Christian H, Veitch J, Astell-Burt T, Hipp JA, Schipperijn J. The impact of interventions to promote physical activity in urban green space: a systematic review and recommendations for future research. Soc Sci Med. 2015;124:246-56.

19. Cohen DA, McKenzie TL, Sehgal A, Williamson S, Golinelli
D, Lurie N. Contribution of public parks to physical activity. Am J Public Health. 2007;97(3):509-14.

20. Manta SW, Lopes AAS, Hino AAF, Benedetti TRB, Rech CR. Espaços públicos de lazer e estruturas para atividade física: estudo de observação sistemática do ambiente. Rev Bras Cineantropom Desempenho Hum. 2018;20(5):445-55.

21. Instituto Brasileiro de Geografia e Estatística. Florianópolis, SC. IBGE; 2010. [citado 2018 Jun 22]. Disponível em: url: https://www.ibge.gov.br/estatisticas-novoportal/por-cidadeestado-estatisticas.html? $\mathrm{t}=$ destaques\&c=4205407.

22. Instituto Brasileiro de Geografia e Estatística. Base de informações do Censo Demográfico: resultados do Universo por setor censitário. Rio de Janeiro: IBGE; 2010.

23. Reis RS, Nascimento JV, Petroski EL. Escala de autopercepção do ambiente para a realização de atividades físicas. Rev Bras Ativ Fís Saúde. 2002;7(2):14-23.

24. Collet C, Chiaradia BM, Reis RS, Nascimento JV. Fatores determinantes para a realização de atividades físicas em parque urbano de Florianópolis. Rev Bras Ativ Fís Saúde. 2008;13(1):15-23.

25. Messa PTD, Fonseca SA, Nahas MV. Mediadores para a prática de atividade física de lazer em usuários do Parque de Coqueiros - Florianópolis, SC. Revista Catarinense de Educação Física. 2006;2(3):3.

26. Fermino RC, Reis RS, Hallal PC, Farias Junior JC. Perceived environment and public open space use: a study with adults from Curitiba, Brazil. Int J Behav Nutr Phys Act. 2013;10:35.

27. Santos MS, Hino AAF, Reis RS, Rodriguez-Añez CR. Prevalência de barreiras para a prática de atividade física em adolescentes. Rev Bras Epidemiol. 2010;13(1):94-104.

28. Reis RS. Determinantes ambientais para a realização de atividades físicas nos parques urbanos de Curitiba: uma abordagem sócio-ecológica da percepção dos usuários [dissertação de mestrado]. Florianópolis: Universidade Federal de Santa Catarina; 2001.

29. Eiras SB, Silva WHA, Souza DL, Vendrusculo R. Fatores de adesão e manutenção da prática de atividade física por parte de idosos. Rev Bras Ciências do Esporte. 2010;31(2):75-89.

Received: 30/07/2018 Approved: 09/02/2019

Quote this article as:

Valenzuela ALEM, Santos ACB, Justina MDD, Kuhn TS, Pazin J, Rech CR. Environmental factors to promote the use of a Public Park in adults. Rev Bras Ativ Fís Saúde. 2018;23:e0049. DOI: 10.12820/rbafs.23e0049 